DOI: https://doi.org/10.47631/jareas.v2i3.300

\title{
Productivity Measurement: A Study of Selected Pharmaceutical Companies in India
}

\section{Dadhaniya Abhisha Chandulal ${ }^{1}$}

${ }^{1}$ Research scholar, Department of Commerce, Saurashtra University, Rajkot-360005, Gujarat, India

\begin{tabular}{|c|c|}
\hline Article Info & Abstract \\
\hline $\begin{array}{l}\text { Article history: } \\
\text { Received:10 July } 2021\end{array}$ & $\begin{array}{l}\text { Purpose: This study aims to measure, analyze, and compare the productivity } \\
\text { performance of selected pharmaceutical companies in India. }\end{array}$ \\
\hline Revised: 28 August 2021 & Approach/Methodology/Design: This study is based on secondary data. In \\
\hline Accepted: 30 August 2021 & $\begin{array}{l}\text { this study, seven pharmaceutical companies are selected as a sample based on } \\
\text { paid-up capital of the year 2019-20. The seven companies are selected for }\end{array}$ \\
\hline & $\begin{array}{l}\text { their higher paid-up capital, and the study period is seven years from 2013-14 } \\
\text { to 2019-20. In this study ratio analysis is used as an accounting tool in which }\end{array}$ \\
\hline Efficiency, Productivity, & four productivity ratios are employed. The one-way ANOVA technique of \\
\hline ity, Labour & parametric test is used as a statistical tool to identify the difference among \\
\hline & sample means. \\
\hline Productivity, Total & Findings: The major findings of the study indicate that in all the selected \\
\hline $\begin{array}{l}\text { Productivity, Pharmaceutical } \\
\text { Sector }\end{array}$ & $\begin{array}{l}\text { companies the performance of material productivity, labor productivity and } \\
\text { overhead productivity show fluctuating trend. The overall productivity } \\
\text { performance of all the companies is very close to each other during the study }\end{array}$ \\
\hline JEL: L1, G31, G38 & $\begin{array}{l}\text { period of seven years. The result of the statistical tests revealed that in all } \\
\text { productivity ratios drawn null hypotheses are not accepted. This means there }\end{array}$ \\
\hline Paper Type : & is a significant difference in different productivity ratios among selected \\
\hline Research Article & $\begin{array}{l}\text { pharmaceutical companies during the study period. } \\
\text { Practical Implications: In this study, productivity analysis is carried out }\end{array}$ \\
\hline $\begin{array}{l}\text { Corresponding Author: } \\
\text { Dadhaniya Chandulal }\end{array}$ & $\begin{array}{l}\text { which is helpful to measure the productivity performance. The results would } \\
\text { help investors to make the right choice of investment in selected } \\
\text { pharmaceutical companies. Given the present situation of COVID-19, } \\
\text { productivity analysis will be helpful to identify the existing production }\end{array}$ \\
\hline $\begin{array}{l}\text { Email: } \\
\text { dadhaniaabhi@gmail.com }\end{array}$ & $\begin{array}{l}\text { capacity in concern with pharmaceutical products and services. } \\
\text { Originality/value: The significant contribution of this study is to measure the } \\
\text { various productivity performances of pharmaceutical companies. Further, the } \\
\text { average productivity performance is compared among the seven selected } \\
\text { pharmaceutical companies, which shows that average productivity } \\
\text { performance is different among the selected companies. }\end{array}$ \\
\hline
\end{tabular}

\section{Introduction}

In simple words, the capacity to produce or the ability to produce is known as productivity. The dictionary meaning of productivity is "the quality or fact of being productive". While productive means "having a quality of production or bringing forth" (Oxford English Dictionary, 1982). "Productivity refers to the physical relationship between the quantity produced (output) and the number of resources used in the course of production (input)". It is the ratio between the output of goods and services and the input of resources consumed in the process of production (Gupta, 1990). Productivity defines as "the ratio between the output of a given commodity measured by its volume and one or more of the input factors also measured by their volumes" (Subramaniam, 1977). 
Productivity is the relationship between output [O] of goods and services and the input [I] of human - non-human resources used in the production process, the relationship is usually expressed in ratio form O/I i.e. output to input. The higher the numerical value of $\mathrm{I}$ in ratio, the greater the productivity (Kendrick, 1965). "Broadly and basically defined, productivity is of course, the relation between output and input a measurement of efficiency with which resources of all kinds are transformed" (Bell, 1960). Thus, productivity is a measure of input efficiency. It indicates how many units of output are obtained from a unit of input. In Short higher productivity means that more is produced with the same expenditure or resources or the same amount is produced at less cost.

Productivity means a balance between all factors of production that will give the maximum output with the smallest effort (Drucker, 1954). Productivity is a ratio of resources generated to the resources consumed in producing them, both measures being expressed as an index in which the current position is compared with the position during a base period (Finch, 1976). Productivity is "the yield obtained from any process or product by employing one or more factors of production. Productivity is usually calculated as an index number; the ratio of output to input" (Cooper \& Ijiri, 1984).

Nowadays productivity has become almost synonymous with progress. It is key to prosperity. There are two ways to increase production. The first is to employ more resources and the second is to utilize the existing resources more efficiently and effectively. As it is well-known fact, that resources are limited and higher productivity is needed for improvement. Higher productivity requires that wastage should be minimized as far as possible by spotting out and eliminating the wastage of materials, manpower, machinery, time, and other resources. Many techniques e.g. inventory control, value analysis, ergonomics, standard quality control, work-study, etc. are used for this purpose. Higher productivity provides better wages and working conditions, better management and enhanced regular source of income and increases the skill and efficiency of workers. Higher productivity brings higher dividends for shareholders and lower prices for consumers. It improves the exports and foreign exchange reserves and makes the country selfsufficient in the production of different items. Thus, it leads to economic growth and social progress. Higher productivity helps in increasing the production volume at a reduced cost and hence enables the expansion of the market and industrial growth. (Maheshwari, 2016).

The Pharmaceutical Industry is engaged in the work of development, production, and marketing of drugs licensed for use as medications. Historically, medicines were prepared by medical doctors and later by apothecaries. For that, they have been facing a variety of laws and regulations provided by the government relating to patenting, pricing, testing, marketing of drugs, ensuring safety, etc. Today, the efforts of highly trained scientists at universities and private companies lead to the development of drugs. The main contribution of industry is to engage technological advancements with innovative research to fulfill the complex healthcare demands of the population. The pharmaceutical industry's main goals are to provide drugs that maintain health, prevent infection, and enhance the life quality of people (Wikipedia, 2021, July 2). 
In the whole world, India ranks $3^{\text {rd }}$ in production whereas ranks $14^{\text {th }}$ in value of the pharmaceutical industry. India has developed a pharmaceutical industry domestically which involves 3000 drugs and 10500 units of manufacturing companies. India is the largest provider of generic drugs at the global level. Indian pharmaceutical industry supplied $50 \%$ of the global demand for various kinds of vaccines, $40 \%$ of generic demand in the USA and $25 \%$ of overall medicine in the UK (IBEF, 2021).

\section{Literature Review}

Productivity shows the efficiency of production of goods or services by a ratio of combined output to a single input or combined input used in the production process. Higher productivity describes the production of extra output from given inputs or production of the same amount with lesser inputs. Several research studies are available in the area of productivity of different sectors. The below literature reviews are the most significant studies in relation to the topic of the present research article.

Manik Mazumdar \& Meenakshi Rajeev (2009) explained the output and input efficiency of Indian manufacturing firms with the case of the pharmaceutical sector in India. They analyzed the competitiveness by calculating the technical efficiency of the Indian pharmaceutical sector. The DEA model was used for the study period of 15 years from 1991- 2005. The researchers found that the output efficiency level of the pharmaceutical sector was in a declining trend and firms have been capable to use raw material input and labor input efficiently.

Manish B. Raval \& Jyotindra M. Jani (2012) carried an analytical study of employee productivity in some selected India nationalized banks. They studied the employee's productivity in selected five nationalized banks with the help of business per employee and profit per employee for the duration of 5 years from 2006-07 to 2010-11. The researchers used two way ANOVA technique of parametric test to test the hypotheses. Their findings showed a significant difference in profit per employee and business per employee between the selected banks. There was no significant difference in profit per employee within the selected banks, and there was a significant difference in business per employee within the selected banks.

Gupta S. K., Gupta S. \& Dhamija P. (2019) have done an empirical study on productivity analysis of the leather industry in India. The main aim of this research work was to analyze the Single Factors Productivity (SFP), Total Factor Productivity (TFP), and Technical Efficiency (TE), of the leather industry in India. The researchers have selected three major states which were Tamil Nadu, Uttar Pradesh and West Bengal to analyze the performance. As the result of the study, the researchers found that the performance of West Bengal was higher in SFP and TE compared to Uttar Pradesh and Tamil Nadu. The researchers also revealed that firm size and SFP have a positive correlation with TE.

Meenu Maheshwari \& Taparia Priya(2019) have measured material productivity with the help of a case study of pharmaceutical companies included in nifty 50. The main aim of this research work was to measure and analyze the material productivity of pharmaceutical companies included in Nifty 50 for the study period of 8 years. The sample size of the study was 4 pharmaceutical companies included in Nifty 50. Both inter-companies and intra-companies

Copyright (C) 2020, Journal of Advanced Research in Economics and Administrative Sciences (JAREAS), Under a 
hypotheses were tested and results were drawn from it. Kruskal wallis test was used to test intercompanies hypothesis and the researchers found that null hypothesis was rejected in all the selected companies. Chi-square test was used to test intra-companies hypothesis and the researchers found that null hypothesis was accepted in all the selected companies except the Sun Pharmaceutical Industries Ltd.

After reviewing the above literature it is found that Manik M. \& Meenakshi R. (2009) explained technical efficiency with DEA model, where manish R. \& Jyotindra J. (2012) analyzed employee's productivity for nationalized banks. Gupta S. K., Gupta S. \& Dhamija P. (2019) analyzed the productivity of the leather industry, while Meenu M. \& Priya T. (2019) have measured only material productivity of pharmaceutical companies. All these reviews and many more research works were done in the area of productivity but no study was done on productivity measurement for selected pharmaceutical companies in India with this particular study period, productivity ratios and statistical tools. Hence, in this present research article, an attempt has been made to measure and analyze the productivity of selected pharmaceutical companies.

\section{Methodology and Procedures}

The type of this research work is analytical and descriptive. This research work is based on secondary data. Financial data is collected from the annual publications of the selected companies. The study period for this research work is seven years from 2013-14 to 2019-20.

Table No. 1.1: Selection of Sample

\begin{tabular}{|c|l|}
\hline Target Population & $\begin{array}{l}\text { All the pharmaceutical companies of India which are listed on NSE } \\
\text { and BSE are considered as population. }\end{array}$ \\
\hline Sampling Method & $\begin{array}{l}\text { Judgment or purposive sampling method of non-probability } \\
\text { technique is considered as the sampling method. }\end{array}$ \\
\hline Sample Size & $\begin{array}{l}\text { Seven pharmaceutical companies are selected as samples based on } \\
\text { paid up capital of the year 2019-20, in that first seven companies } \\
\text { which possess higher paid up capital are selected. }\end{array}$ \\
\hline Selection of & $\begin{array}{l}\text { 1. Sun Pharmaceutical Industries Ltd. } \\
\text { Sample }\end{array}$ \\
$\begin{array}{l}\text { 2. Cipla Ltd. } \\
\text { 3. Laurus Labs Ltd. } \\
\text { 4. Cadila Healthcare Ltd. } \\
\text { 5. Lupin Ltd. }\end{array}$ \\
$\begin{array}{l}\text { 6. Strides Pharma Science Ltd. } \\
\text { 7. Torrent Pharmaceuticals Ltd. }\end{array}$ \\
\hline
\end{tabular}

The functional scope of this research work is to analyze the productivity performance of selected pharmaceutical companies. In this research work, the selected seven pharmaceutical companies produce health products in India. The whole country is considered as geographical scope. The accounting tool used for this research work is ratio analysis in which four productivity ratios are used i.e. material productivity ratio, labor productivity ratio, overhead productivity ratio, and total productivity ratio. The statistical tool used for this research work is arithmetic mean and one-way ANOVA technique of parametric test and graphical representation of companies' performance in different ratios. 


\section{Results and Discussion}

The numerical data is collected from annual reports of selected pharmaceutical companies. For data analysis, four productivity ratios are used i.e. material productivity ratio, labor productivity ratio, overhead productivity ratio, and total productivity ratio. Which are as follows.

\section{Material Productivity Ratio:}

The material productivity ratio is the division of total output to materials input. In the cost of production, material productivity plays a very important role. Material productivity relies upon how effectively material is utilized in the conversion of finished products. Material productivity is increased by employing skilled staff, sufficient machine tools, proper design of product, etc. Symbolically, it is expressed as under.

$$
\text { Material Productivity Ratio }=\frac{\text { Total Output }}{\text { Material Input }}
$$

Table No. 1.2: Material Productivity Ratio

\begin{tabular}{|c|r|r|r|r|r|r|r|}
\hline Years & \multicolumn{1}{|c|}{$\begin{array}{c}\text { Sun } \\
\text { Pharma }\end{array}$} & \multicolumn{1}{c|}{ Cipla } & $\begin{array}{c}\text { Laurus } \\
\text { Labs }\end{array}$ & $\begin{array}{c}\text { Cadila } \\
\text { Healthcare }\end{array}$ & Lupin & $\begin{array}{c}\text { Strides } \\
\text { Pharma }\end{array}$ & $\begin{array}{c}\text { Torrent } \\
\text { Pharma }\end{array}$ \\
\hline $\mathbf{2 0 1 3 - 1 4}$ & 2.62 & 2.41 & 1.46 & 2.79 & 3.02 & 1.69 & 3.47 \\
\hline $\mathbf{2 0 1 4 - 1 5}$ & 2.51 & 2.34 & 1.45 & 3.06 & 3.07 & 1.78 & 2.97 \\
\hline $\mathbf{2 0 1 5 - 1 6}$ & 2.61 & 2.59 & 1.76 & 3.87 & 3.29 & 1.74 & 4.41 \\
\hline $\mathbf{2 0 1 6 - 1 7}$ & 2.25 & 2.51 & 1.86 & 2.83 & 3.62 & 2.10 & 3.29 \\
\hline $\mathbf{2 0 1 7 - 1 8}$ & 2.38 & 2.62 & 1.89 & 3.09 & 2.98 & 1.84 & 3.15 \\
\hline $\mathbf{2 0 1 8 - 1 9}$ & 2.63 & 3.03 & 1.81 & 3.10 & 2.81 & 1.66 & 3.72 \\
\hline $\mathbf{2 0 1 9 - 2 0}$ & 2.83 & 2.90 & 1.73 & 3.28 & 2.60 & 1.89 & 3.64 \\
\hline Average & 2.55 & 2.63 & 1.71 & 3.15 & 3.06 & 1.81 & 3.52 \\
\hline Minimum & 2.25 & 2.34 & 1.45 & 2.79 & 2.6 & 1.66 & 2.97 \\
\hline Maximum & 2.83 & 3.03 & 1.89 & 3.87 & 3.62 & 2.1 & 4.41 \\
\hline
\end{tabular}

Source: Calculated From Published Annual Reports of Selected Companies 


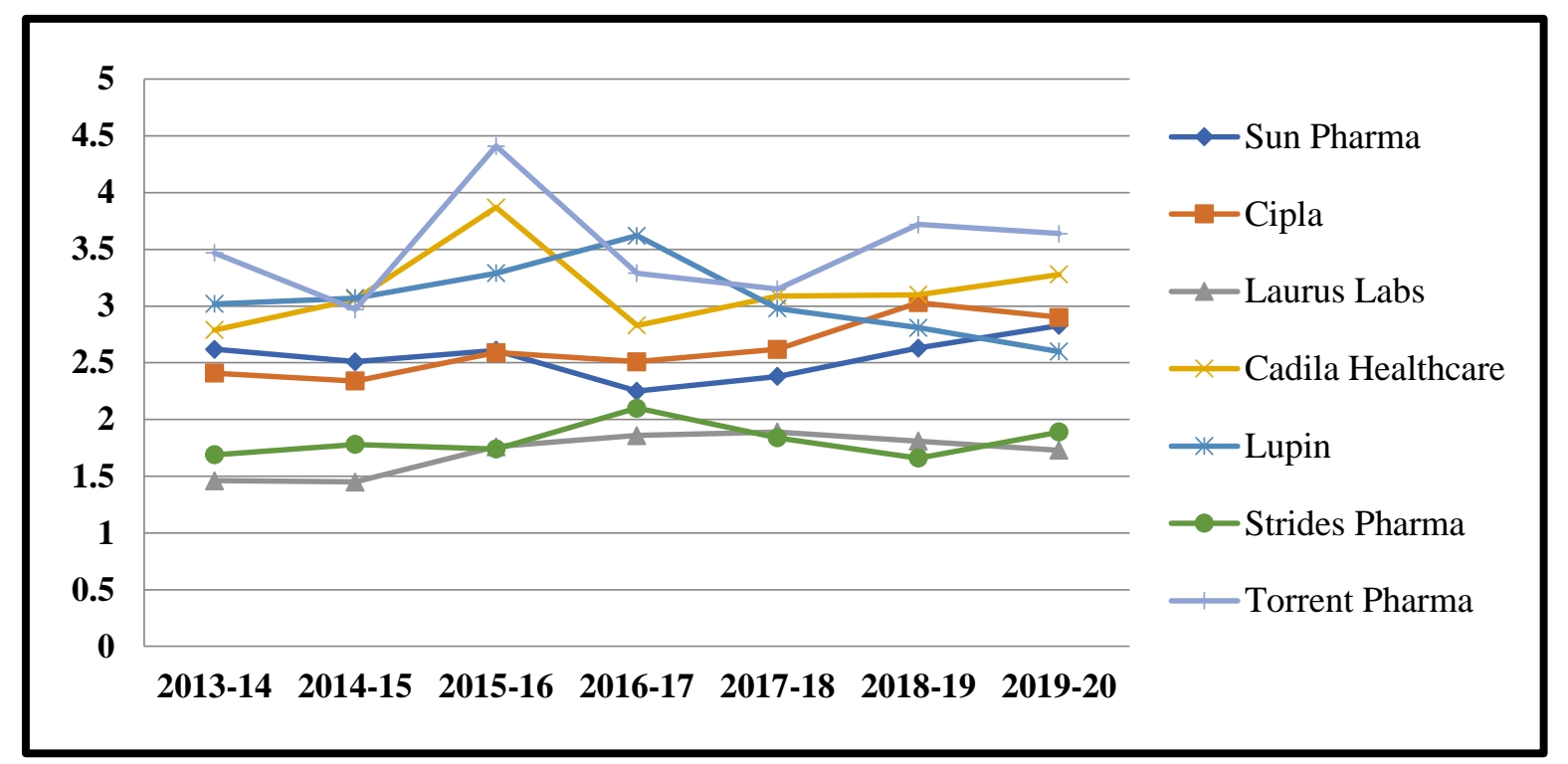

Graph No. 1.1: Material Productivity Ratio

In all the selected companies, the fluctuating trend is indicated for the material productivity ratio to the time span of seven years from 2013-14 to 2019-20. The minimum ratio was 1.45 in Laurus Labs Ltd. in 2014-15 and the maximum ratio was 4.41 in Torrent Pharmaceuticals Ltd. in 201516. About the average ratio of 7 years, the lowest ratio 1.71 showed in Laurus Labs Ltd. and the highest ratio 3.52 showed in Torrent Pharmaceuticals Ltd. Average ratio in Cadila Healthcare Ltd. and Lupin Ltd. were 3.15 and 3.06 for both companies and this average ratio was near to highest average ratio. The average ratio in Sun Pharmaceutical Industries Ltd. and Cipal Ltd. was were2.55 and 2.63 for both companies and this average ratio was in the middle of the highest average ratio and lowest average ratio. The average ratio of Strides Pharma Science Ltd. was 1.81 which was near to the lowest average ratio.

The overall Performance of material productivity ratio in Torrent Pharmaceuticals Ltd., Lupin Ltd. and Cadila Healthcare Ltd. was better, in Cipla Ltd. \&Sun Pharmaceuticals Industry Ltd. it was moderate and in Strides Pharma Science Ltd. \&Laurus Labs Ltd. it was low in comparison to other selected companies.

Labor Productivity Ratio: The labor productivity ratio is the division of output into labor input. Labor productivity depends upon the actual utilization of labors. High or low labor productivity depends on factors like workload, material, availability of power, working tools, work efficiency, motivation level, training level, working condition, etc. Symbolically, it is expressed as under.

$$
\text { Labor Productivity Ratio }=\frac{\text { Total Output }}{\text { Labor Input }}
$$

Table No. 1.3: Labor Productivity Ratio

\begin{tabular}{|c|r|r|r|r|r|r|r|}
\hline Years & $\begin{array}{c}\text { Sun } \\
\text { Pharma }\end{array}$ & Cipla & $\begin{array}{c}\text { Laurus } \\
\text { Labs }\end{array}$ & $\begin{array}{c}\text { Cadila } \\
\text { Healthcare }\end{array}$ & Lupin & $\begin{array}{c}\text { Strides } \\
\text { Pharma }\end{array}$ & $\begin{array}{c}\text { Torrent } \\
\text { Pharma }\end{array}$ \\
\hline $2013-14$ & 10.12 & 7.36 & 11.14 & 7.70 & 10.11 & 9.55 & 8.03 \\
\hline
\end{tabular}




\begin{tabular}{|c|r|r|r|r|r|r|r|}
\hline $2014-15$ & 5.39 & 6.73 & 10.24 & 8.70 & 9.27 & 7.73 & 6.85 \\
\hline $2015-16$ & 5.33 & 6.81 & 10.64 & 10.24 & 9.31 & 8.10 & 9.51 \\
\hline $2016-17$ & 5.20 & 6.35 & 8.81 & 5.28 & 9.09 & 5.31 & 6.57 \\
\hline $2017-18$ & 4.91 & 6.41 & 8.56 & 9.30 & 7.00 & 6.54 & 5.14 \\
\hline $2018-19$ & 6.56 & 6.73 & 8.29 & 6.28 & 7.49 & 6.89 & 5.68 \\
\hline $2019-20$ & 7.36 & 6.62 & 8.63 & 5.89 & 6.47 & 7.55 & 5.81 \\
\hline Average & 6.41 & 6.72 & 9.47 & 7.63 & 8.39 & 7.38 & 6.80 \\
\hline Minimum & 4.91 & 6.35 & 8.29 & 5.28 & 6.47 & 5.31 & 5.14 \\
\hline Maximum & 10.12 & 7.36 & 11.14 & 10.24 & 10.11 & 9.55 & 9.51 \\
\hline
\end{tabular}

Source: Calculated From Published Annual Reports of Selected Companies

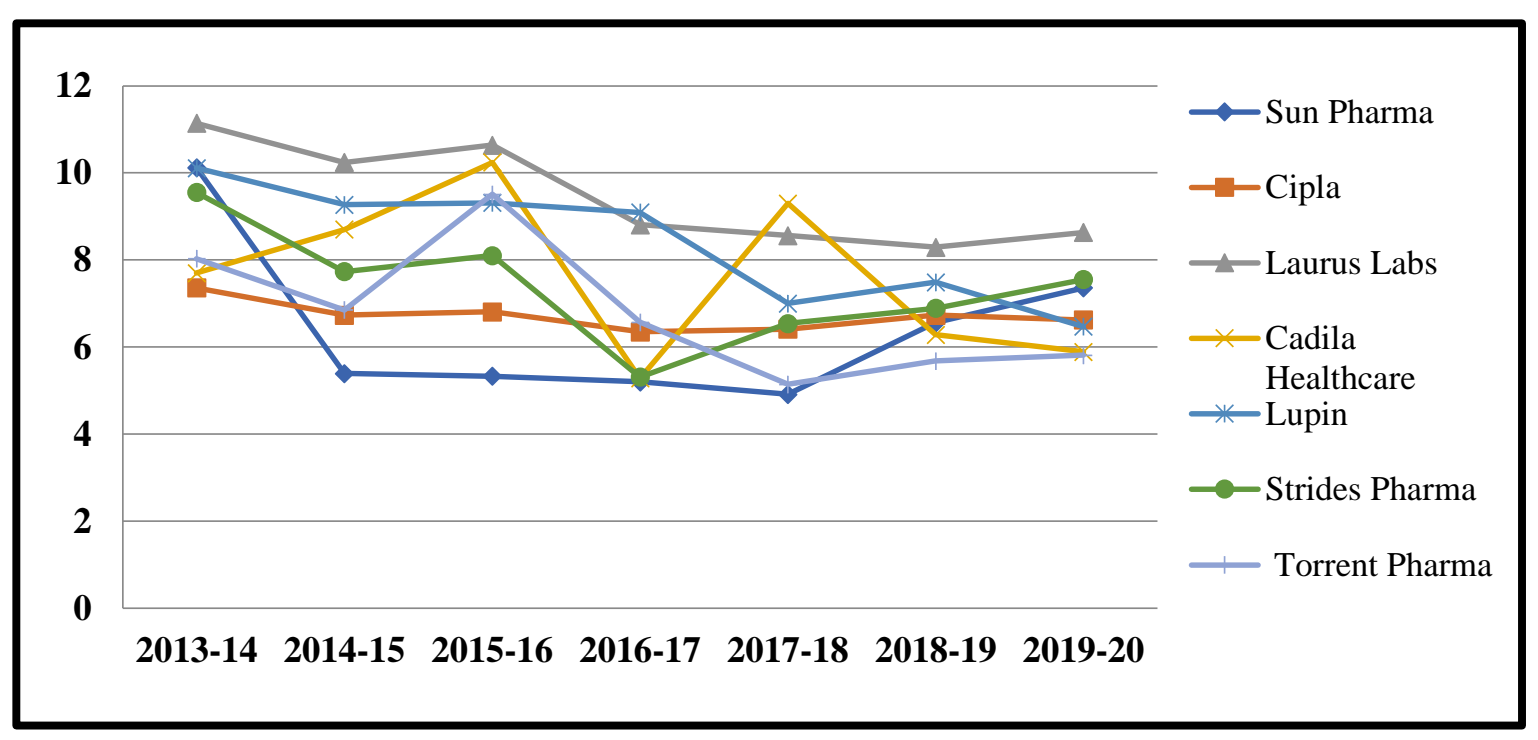

Graph No. 1.2: Labor Productivity Ratio

In all the selected companies mixed trend is indicated for the labor productivity ratio to the time span of 2013-14 to 2019-20. Sun Pharmaceutical Industries Ltd. showed the minimum ratio of 4.91in 2017-18 and Laurus Labs Ltd. showed the maximum ratio of 11.14in2013-14. In context to average ratio of sample companies during the time period highest ratio i.e. 9.47 showed by Laurus Labs Ltd. and lowest ratio i.e. 6.41 showed by Sun Pharmaceutical Industries Ltd. Average ratio in Cipla Ltd. and Torrent Pharmaceuticals Ltd. were 6.72 and 6.80 respectively and that average ratios were near to the lowest average ratio. The average ratio in Lupin Ltd. was 8.39 that was near to the highest average ratio. The average ratio in Cadila Healthcare Ltd. and Strides Pharma Science Ltd. were 7.63 and 7.38 respectively and the average ratios were in between the highest average ratio and lowest average ratio.

The overall performance of labor productivity ratio was good in Lupin Ltd. and Laurus Labs Ltd. It was moderate in Strides Pharma Science Ltd. and Cadila Healthcare Ltd. It was poor in Torrent Pharmaceuticals Ltd., Sun Pharmaceutical Industries Ltd., and Cipla Ltd. in comparison to all sample companies.

Overhead Productivity Ratio: Overhead productivity ratio is the division of total output to overhead input. Production cost, administrative or office cost, selling and distribution cost is 
included in overhead costs. It can be known as the other costs than the direct costs. Symbolically, it is expressed as under.

$$
\text { Overhead Productivity Ratio }=\frac{\text { Total Output }}{\text { Overhead Input }}
$$

Table No. 1.4: Overhead Productivity Ratio

\begin{tabular}{|c|r|r|r|r|r|r|r|}
\hline Years & $\begin{array}{c}\text { Sun } \\
\text { Pharma }\end{array}$ & Cipla & $\begin{array}{c}\text { Laurus } \\
\text { Labs }\end{array}$ & $\begin{array}{c}\text { Cadila } \\
\text { Healthcare }\end{array}$ & Lupin & $\begin{array}{c}\text { Strides } \\
\text { Pharma }\end{array}$ & $\begin{array}{c}\text { Torrent } \\
\text { Pharma }\end{array}$ \\
\hline $2013-14$ & 2.17 & 4.14 & 9.83 & 3.17 & 4.00 & 5.10 & 4.23 \\
\hline $2014-15$ & 2.39 & 4.01 & 7.19 & 3.58 & 4.25 & 4.22 & 3.40 \\
\hline $2015-16$ & 2.86 & 4.19 & 8.26 & 3.82 & 4.02 & 5.92 & 5.38 \\
\hline $2016-17$ & 2.94 & 4.11 & 7.46 & 2.56 & 3.76 & 4.83 & 3.66 \\
\hline $2017-18$ & 3.28 & 3.40 & 5.24 & 3.71 & 3.30 & 5.79 & 3.14 \\
\hline $2018-19$ & 4.00 & 4.05 & 7.05 & 3.89 & 3.73 & 5.67 & 3.76 \\
\hline $2019-20$ & 4.34 & 3.99 & 5.71 & 3.42 & 3.49 & 5.12 & 4.18 \\
\hline Average & 3.14 & 3.98 & 7.25 & 3.45 & 3.79 & 5.24 & 3.96 \\
\hline Minimum & 2.17 & 3.4 & 5.24 & 2.56 & 3.3 & 4.22 & 3.14 \\
\hline Maximum & 4.34 & 4.19 & 9.83 & 3.83 & 4.25 & 5.92 & 5.38 \\
\hline
\end{tabular}

\section{Source: Calculated From Published Annual Reports of Selected Companies}

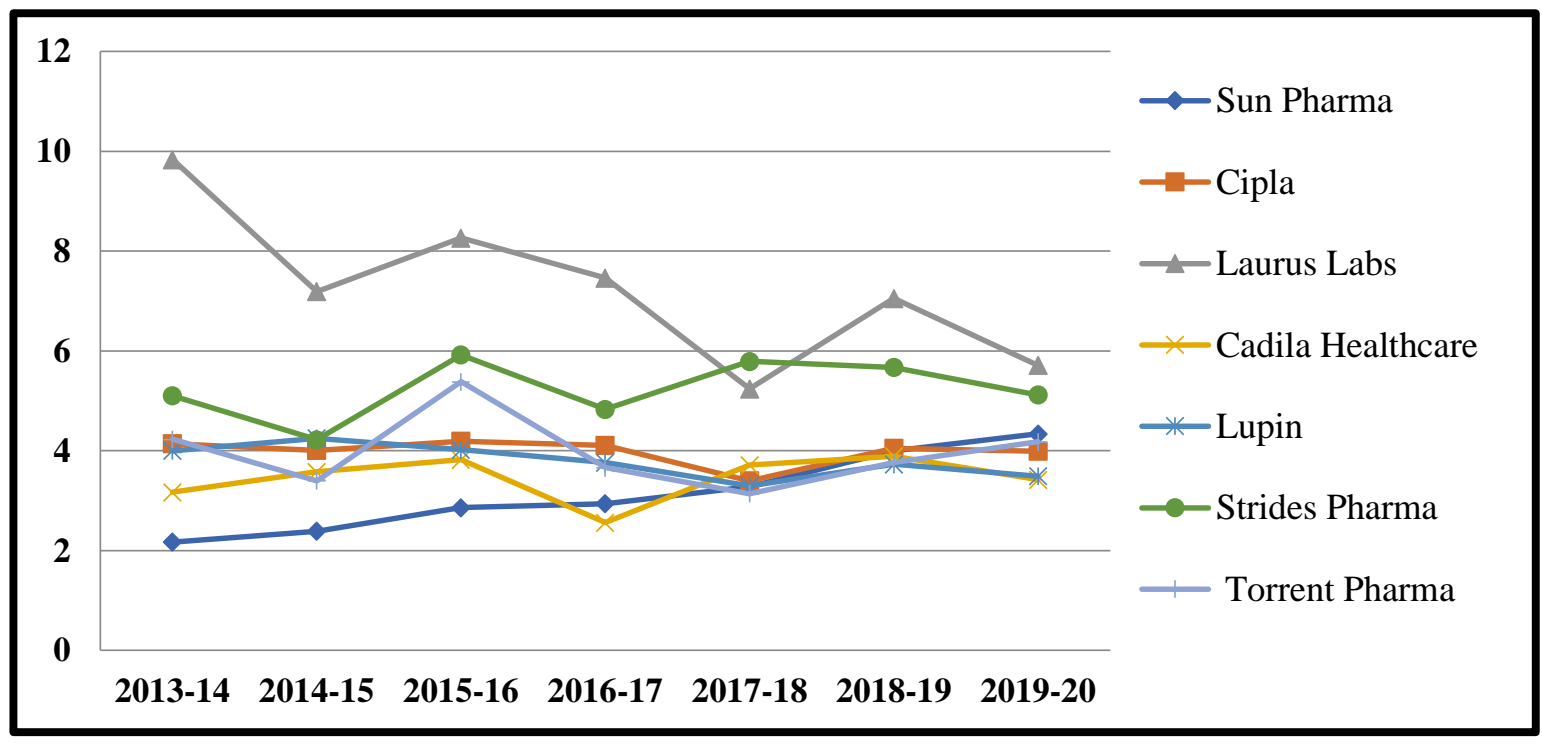

Graph No. 1.3: Overhead Productivity Ratio

In all the selected companies fluctuating trend was indicated in the overhead productivity ratio except Sun Pharmaceutical Industries Ltd. in which the ratio shows the rising trend for the study period from 2013-14 to 2019-20. Laurus Labs Ltd. showed a maximum ratio of 9.83in the year 2013-14and Sun Pharmaceutical Industries Ltd. showed a minimum ratio of 2.17 in the year2013-14. About average ratio of seven years highest ratio i.e. 7.25 showed by Laurus Labs Ltd. and the lowest ratio i.e. 3.14 showed by Sun Pharmaceutical Industries Ltd. In Cadila Healthcare Ltd., Cipla Ltd., Lupin Ltd., and Torrent Pharmaceuticals Ltd. average ratio was $3.45,3.98,3.79$, and 3.96 respectively; in these companies average ratio was near to the lowest 
average ratio. The average ratio of 5.24 showed by Strides Pharma Science Ltd. which was in between the highest average ratio and lowest average ratio.

The Overall performance of the overhead productivity ratio in Laurus Labs Ltd. was good. In Strides Pharma Science Ltd. it was moderate. In Sun Pharmaceutical Industries Ltd., Cadila Healthcare Ltd., Cipla Ltd., Lupin Ltd., and Torrent Pharmaceuticals Ltd. it was poor in comparison to all selected companies.

Total productivity Ratio: Total productivity is the method of calculating productivity that considers all the resources as a whole. It can be known as 'overall productivity'. A single figure gives an idea about the efficiency of entire organizations called total productivity. It is a qualitative and systematic approach that completes the products with the consideration of quality, price and time.

Total Productivity Ratio $=\frac{\text { Total Output }}{\text { Total Input }}$

Table No. 1.5: Total Productivity Ratio

\begin{tabular}{|c|r|r|r|r|r|r|r|}
\hline Years & $\begin{array}{c}\text { Sun } \\
\text { Pharma }\end{array}$ & Cipla & $\begin{array}{c}\text { Laurus } \\
\text { Labs }\end{array}$ & $\begin{array}{c}\text { Cadila } \\
\text { Healthcare }\end{array}$ & Lupin & $\begin{array}{c}\text { Strides } \\
\text { Pharma }\end{array}$ & $\begin{array}{c}\text { Torrent } \\
\text { Pharma }\end{array}$ \\
\hline $2013-14$ & 1.06 & 1.26 & 1.14 & 1.24 & 1.48 & 1.12 & 1.54 \\
\hline $2014-15$ & 1.00 & 1.21 & 1.08 & 1.39 & 1.49 & 1.08 & 1.29 \\
\hline $2015-16$ & 1.09 & 1.30 & 1.27 & 1.62 & 1.52 & 1.15 & 1.93 \\
\hline $2016-17$ & 1.02 & 1.29 & 1.28 & 1.07 & 1.53 & 1.15 & 1.37 \\
\hline $2017-18$ & 1.08 & 1.26 & 1.19 & 1.36 & 1.28 & 1.15 & 1.20 \\
\hline $2018-19$ & 1.28 & 1.34 & 1.23 & 1.35 & 1.32 & 1.08 & 1.41 \\
\hline $2019-20$ & 1.39 & 1.34 & 1.15 & 1.30 & 1.21 & 1.17 & 1.46 \\
\hline Average & 1.13 & 1.29 & 1.19 & 1.33 & 1.40 & 1.13 & 1.46 \\
\hline Minimum & 1.00 & 1.21 & 1.08 & 1.07 & 1.21 & 1.08 & 1.20 \\
\hline Maximum & 1.39 & 1.34 & 1.28 & 1.62 & 1.53 & 1.17 & 1.93 \\
\hline
\end{tabular}

Source: Calculated From Published Annual Reports of Selected Companies

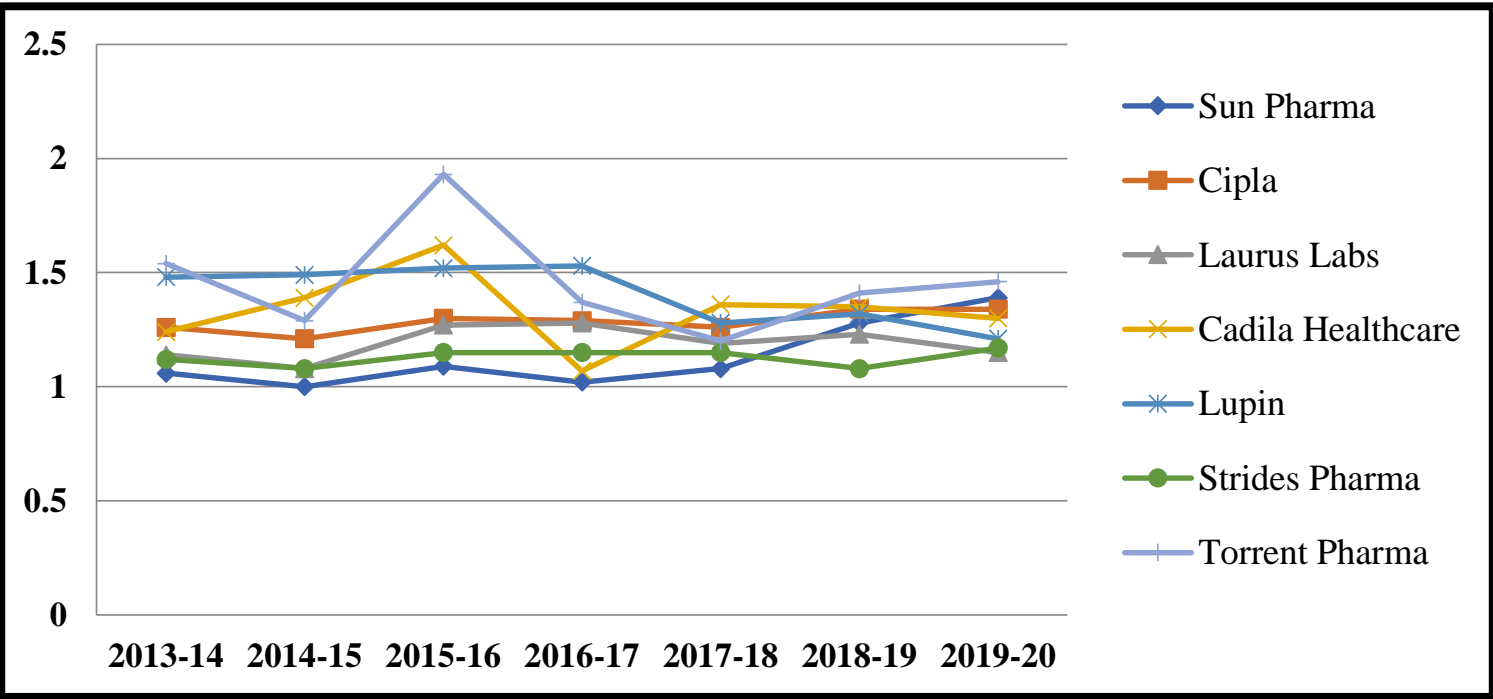

Graph No. 1.4: Total Productivity Ratio

Copyright (C) 2020, Journal of Advanced Research in Economics and Administrative Sciences (JAREAS), Under a 
In all selected companies minor fluctuating trend is indicated for the total productivity ratio to the time span of seven years from 2013-14 to 2019-20. Torrent Pharmaceuticals Ltd showed the maximum ratio of 1.93 in the year 2015-16 and Sun Pharmaceutical Industries Ltd. shows a minimum ratio of 1.0 in the year 2014-15. In context to average ratio of sample companies during the time period highest ratio i.e. 1.46 showed by Torrent Pharmaceuticals Ltd. and the ratio i.e. 1.13 showed by Strides Pharma Science Ltd. and Sun Pharmaceutical Industries Ltd. In Laurus Labs Ltd., Cipla Ltd., Cadila Healthcare Ltd., and Lupin Ltd. the average ratio was 1.19, $1.29,1.33$, and 1.40 respectively.

In all the selected companies, total productivity performance was near to each other so precisely it cannot be said that which selected company is performing good or poor.

\section{One-Way ANOVA for Hypothesis Testing}

Null Hypothesis [ $\left.\mathbf{H}_{0}\right]$ : There is no significant difference in different productivity ratios among selected pharmaceutical companies during the study period.

Alternative Hypothesis [H1]: There is a significant difference in different productivity ratios among selected pharmaceutical companies during the study period.

Table No 1.6: One-Way ANOVA Test

\begin{tabular}{|c|l|c|c|c|c|}
\hline $\begin{array}{c}\text { Sr. } \\
\text { No. }\end{array}$ & \multicolumn{1}{|c|}{ Productivity Ratios } & $\begin{array}{c}\text { Calculated } \\
\text { Value }\end{array}$ & $\begin{array}{c}\text { Table } \\
\text { Value }\end{array}$ & $\begin{array}{c}\text { Level of } \\
\text { Significance }\end{array}$ & $\begin{array}{c}\text { Results of } \\
\mathrm{H}_{0}\end{array}$ \\
\hline 1. & Material Productivity Ratio & 36.609 & 2.324 & $5 \%$ & Rejected \\
\hline 2. & Labor Productivity Ratio & 3.964 & 2.324 & $5 \%$ & Rejected \\
\hline 3. & Overhead Productivity Ratio & 22.855 & 2.324 & $5 \%$ & Rejected \\
\hline 4. & Total Productivity Ratio & 6.400 & 2.324 & $5 \%$ & Rejected \\
\hline
\end{tabular}

The above table indicated that in all selected productivity ratios the calculated value is more than the table value so it is said that null hypotheses are rejected. This means there is a significant difference in different productivity ratios among selected pharmaceutical companies during the study period.

The result of ratio analysis revealed that in material productivity ratio, labor productivity ratio and overhead productivity ratio shows mixed or fluctuating trend, whereas total productivity ratio shows a minor fluctuating trend and the ratio was very close to each other. In the material productivity ratio, the performance of Torrent Pharmaceuticals Ltd. was best and Laurus Labs Ltd. was relatively poor. In labor and overhead productivity ratios, the performance of Laurus Labs Ltd. was best and Sun Pharmaceutical Industries Ltd. was relatively poor. In total productivity ratio, the performance of Torrent pharmaceuticals Ltd. was best and Sun Pharmaceutical Industries Ltd. and Strides Pharma Science Ltd. were relatively poor. It can be said that higher productivity can only be achieved through better utilization of limited resources. (Mazumdar, M. \& Rajeev, M., 2009) found that the output efficiency level of the pharmaceutical sector was in a declining trend and firms have been capable to use raw material input and labor input efficiently.

Copyright (C) 2020, Journal of Advanced Research in Economics and Administrative Sciences (JAREAS), Under a 
The result of statistical test one-way ANOVA shows all selected productivity ratios null hypotheses are rejected and alternative hypotheses are accepted. This means there is a difference in the average performance of selected pharmaceutical companies during the study period. (Maheshwari, M. \& Taparia, P. 2019) found that in the Chi-square test, the null hypotheses are accepted which indicated that the ratio of material productivity was similar among the pharmaceutical companies included in Nifty 50. In the Kruskal Wallis test, the null hypotheses are rejected, which indicated that the ratio of material productivity was different among the pharmaceutical companies included in Nifty 50.

\section{Conclusion and Suggestion}

The present study measured and analyzed the productivity performance of selected pharmaceutical companies with the help of material productivity, labor productivity, overhead productivity, and total productivity. The data analysis indicated that the performance of material productivity, labor productivity and overhead productivity in all the selected companies shows a fluctuating trend. In addition, the performance of overall productivity was very close to each other in the study period. Based on the statistical analysis, the null hypothesis is rejected in all productivity ratios. This means the significant difference is shown in the different productivity ratios among the selected companies during the study period.

\section{Conflict of Interests}

The authors declare no conflict of interest.

\section{Funding}

For this research work, the authors did not receive funds from any organization.

\section{References}

Abdulkareem, A. M. (2020). Financial Performance of Indian Pharmaceutical Companies: Analysis of Leverage and Cost of Capital. Journal of Advanced Research in Economics and Administrative Sciences, 1(1), 13-22. https://doi.org/10.47631/jareas.v1i1.15

Bell, J. F. (1960). Productivity: Its Measuring and Management. In meeting the productivity challenge. American Management Association Inc., New York.

Cooper, W. W. \& Ijiri, Y. (1984). Kohler's Dictionary for Accountants. New Delhi: PrenticeHall of India Pvt. Ltd.

Drucker, P. F. (1954). The Practice of Management. New York: Mc Graw Hill.

Finch, F. (1976). A Concise Encyclopedia of Management Techniques. London: William Heinemann Limited.

Gupta, C. B. (1990). Production, Productivity and Cost Effectiveness. New Delhi: Sultan Chand \&Sons.

Gupta, S. K., Gupta S. \& Dhamija, P. (2019). An Empirical Study on Productivity Analysis of Indian Leather Industry. Benchmarking: An International Journal, 26 (3), 815-835.

Indian Brand Equity Foundation. (2021, July 2). Indian Pharmaceutical Industry. https://www.ibef.org/industry/indian-pharmaceuticals-india.aspx

Kendrick, J. W. (1965). Measuring Company Productivity: Handbook with case studies. New

Copyright (C) 2020, Journal of Advanced Research in Economics and Administrative Sciences (JAREAS), Under a Creative Commons Attribution 4.0 International License 
York: National Industrial Conference Board.

Maheshwari M. (2016). Productivity: A Conceptual Framework. Indian Journal of Research,5(10), 256

Maheshwari, M. \& Taparia, P. (2019). Measurement of Material Productivity: A Case Study of Pharmaceutical Sector Companies included in Nifty 50. Productivity, 60 (2), 175-194.

Mazumdar, M. \& Rajeev, M. (2009). Output and Input Efficiency of Manufacturing Firms in India: A Case of the Indian Pharmaceutical Sector. Institute for Social and Economic Change , 1-36

Raval, M. B. \& Jani, J. M. (2012). An Analytical Study on Empoyee's Productivity in Some Selected Nationalized Banks of India. Indian Journal of Applied Research, 1 (9), 19-20. Subramaniam, K.N. (1977). Wages in India. New Delh: Tata Mc Graw Hill Book Co. 